\title{
Potential of Wastewater Valorization after Wet Extraction of Proteins from Faba Bean and Pea Flours
}

\author{
Sofía Albolafio ${ }^{1}$, María I. Gil ${ }^{1}$, Ana Allende ${ }^{1}$, Epameinondas Xanthakis ${ }^{2,}{ }^{*}$
}

1. Research Group on Microbiology and Quality of Fruit and Vegetables, Food Science and Technology Department, CEBAS-CSIC, P.O. Box 164, E-30100 Espinardo, Spain; E-Mails: salbolafio@cebas.csic.es; migil@cebas.csic.es; aallende@cebas.csic.es

2. RISE-Research Institutes of Sweden, Unit of Agrifood \& Bioscience, Frans Perssons Väg 6, 41276, Gothenburg, Sweden; E-Mail: epameinondas.xanthakis@ri.se

* Correspondence: Epameinondas Xanthakis; E-Mail: epameinondas.xanthakis@ri.se

Academic Editor: Alberto Romero, Victor Perez-Puyana and Mercedes Jiménez-Rosado

Special Issue: Characterization, Recovery and Valorization of Protein Concentrates from Residues and By-products of Agri-food Industry

Recent Progress in Materials

2021, volume 3, issue 2

doi:10.21926/rpm.2102013
Received: December 02, 2020

Accepted: April 07, 2021

Published: April 21, 2021

\begin{abstract}
The present study aimed to characterize wastewater fractions obtained after the wet extraction of proteins from legumes. In addition, the suitability of wastewater fractions for the potential recovery of high value-added compounds was also examined, and consequently, the prevention of the environmental impact of these wastes was explored. Similar to the industrial production of proteins, wet alkaline and acidic extractions of proteins from faba bean and pea flours were performed in two stages of extraction. The different wastewater fractions were characterized by measuring their organic matter content, total solids (TS), total dissolved solids (TDS), electrical conductivity (EC), $\mathrm{pH}$, and turbidity. The value-added compounds from these wastewater fractions were quantified, which included the protein content, carbohydrate content, phenolic content, and antioxidant activity. In addition, the phenolic compounds in these factions were identified and quantified. It was observed that the fractions obtained in the first extraction stage had $60 \%-90 \%$ higher organic matter
\end{abstract}

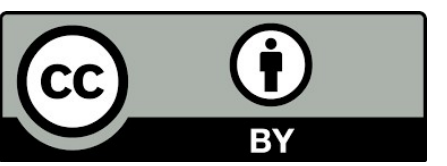

(C) 2021 by the author. This is an open access article distributed under the conditions of the Creative Commons by Attribution License, which permits unrestricted use, distribution, and reproduction in any medium or format, provided the original work is correctly cited. 
content, measured as the chemical oxygen demand (COD), compared to the second fractions, indicating a higher environmental impact of the former in case of disposal. The results obtained for COD, TS, TDS, EC, $\mathrm{pH}$, and turbidity demonstrated that microfiltration reduced only the turbidity (85\%), and consequently, a decrease was observed in the particulate matter, while there was a practically negligible reduction in the soluble matter. Wastewater from faba exhibited the highest polyphenol content and antioxidant activity, and was, therefore, considered the most valuable fraction for potential valorization.

\section{Keywords}

Protein extraction; food industry; sidestreams; potential recovery; high value-added compounds

\section{Introduction}

The wastewater from industrial processes involving the use of fruits and vegetables contains organic matter and nutrients in huge amounts, which has raised environmental concerns [1]. It remains a challenge for the food industry to implement wastewater strategies for reducing the environmental impact of the disposal and recovering potential bioactive substances. Wastewater from the agro-food industries contains a variety of high value-added nutrients and bioactive compounds, such as proteins, unsaturated fatty acids, dietary fibers, and polyphenols [2], and nowadays, there is a growing demand for healthy food products containing such functional proteins and bioactive ingredients. However, concern regarding the environmental impact of the production of animal proteins is also increasing these days. As a consequence, the exploration of novel sources of plant-derived proteins is gaining momentum. In this context, the recovery of high value-added compounds from the wastewater discarded from the industries using fruits and vegetables is worth exploring. After the recovery of bioactive compounds from the wastewater, subsequent wastewater technologies for cleaning and recycling could be better applied. The food industry has large water consumption, while the reuse of water has been minimal due to legislation constraints and hygiene concerns [3]. Manzocco et al. [4] reported innovative technological solutions based on either physical or chemical strategies to treat the wastewater released from processing plants.

Legume proteins may be isolated from the flours obtained from milled seeds using a wet process of extraction under alkaline or acidic conditions. In this process, low molecular weight water-soluble components and soluble proteins are extracted from the flour [5], and subsequently, the globular proteins are isolated using a selective precipitation step at the isoelectric point. The isolated globular proteins are then neutralized and dried to achieve a final protein content of approximately $85 \%$ [5]. Faba beans (Vicia faba) and peas (Pisum sativum) are legumes that are attracting increasing attention as sources for obtaining plant-based proteins. The chemical compositions of faba beans and peas may vary with the variety, maturity, and growing conditions of the plants. Faba beans contain $55 \%-62 \%$ carbohydrates, $26 \%-35 \%$ proteins, and $0.7 \%-2.0 \%$ fats [6]. The faba bean proteins comprise approximately $80 \%$ globulin storage proteins, vicilin, and legumin [7]. Peas contain $60 \%-65 \%$ carbohydrates, $23 \%-31 \%$ proteins, and $1.5 \%-2.0 \%$ fats [8], and the majority of their protein content comprises globulins (55\%-65\%) and albumins (18\%-25\%), which together 
account for approximately $80 \%$ of total protein content [5]. In addition, faba beans and peas contain small amounts of bioactive compounds, such as vitamins, minerals, and polyphenols [8, 9]. Several previous studies have reported the polyphenol content in faba and pea flours, with the phenolic content and antioxidant activity of faba bean flour being higher than that of pea flour [10].

In large-scale industrial processes producing protein isolates, water is consumed in huge amounts, and consequently, high volumes of wastewater are generated. Therefore, developing innovative technologies to recycle and reuse this wastewater generated in protein isolation processes is of great significance. Such technologies should be able to remove the undesirable physical and chemical components while also controlling and preventing the potential growth of pathogenic and degradation-causing organisms [3]. Recently, Chen et al. [2] described the application of different technologies for the recovery of bioactive substances from the wastewater generated from fruit and vegetable processing industries. Physical methods based on membrane separation technologies have been applied previously for water recycling and recovery of the byproducts present in wastewaters [3]. Such treatments allow the safe discharge of wastewater after the potential recovery of high value-added components. Ultrafiltration (UF) and nanofiltration (NF) membranes have been used to recover bioactive compounds from the wastewater generated from the agro-food industry [11]. However, such methods have certain limitations as the waste streams released from different industries are quite different, and the recovery technologies must, therefore, be tailored for each specific condition [2].

The present study was aimed to characterize different wastewater fractions obtained after the alkaline and acidic wet extraction processes applied for the production of protein isolates from faba bean and pea flours, adapting the procedure performed on the industrial upscale to the laboratory scale. Data were obtained depending on the type of extraction (alkaline and acidic fractions), the extraction process (first and second stages), and the type of matrix used (faba bean and pea flours). In addition, the value-added compounds, including carbohydrates and phenolic compounds, that could potentially be recovered from these wastewater fractions were identified and quantified.

\section{Materials and Methods}

\subsection{Chemicals}

The chemical reagents used were: hydrochloric acid solution 32 wt. \% in $\mathrm{H}_{2} \mathrm{O}, \mathrm{FCC}$ (Sigma-Aldrich,

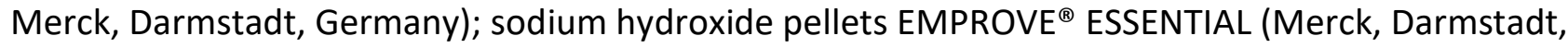
Germany); gallic acid monohydrate ACS reagent $\geq 98.0 \%$ (Sigma-Aldrich, Merck, Darmstadt, Germany); sodium bicarbonate ACS reagent $\geq 99.7 \%$ (Merck, Darmstadt, Germany); methanol ACS EMSURE $^{\circledR}$ (Merck, Darmstadt, Germany); Folin and Ciocalteu's Phenol reagent (MP Biomedicals, Valiant Co. Ltd., China); 2,2-Diphenyl-1-picrylhydrazyl (free radical) 95\% (Alfa Aesar, Thermo Fisher Scientific, Kandel, Germany); absolute ethanol $\geq 99.8 \%$; AnalaR NORMAPUR ${ }^{\circledR}$ ACS (VWR, West Chester, Pennsylvania, United States); formic acid 98\% for ACS analysis (PanReac AppliChem, ITW Reagents, Chicago, USA); acetonitrile Optima LC/MS grade (Fisher Chemical, Pittsburgh, PA, USA); and ultrapure water (MilliQ Advantage A10 water purification system, Millipore, Billerica, MA, USA). 


\subsection{Extraction of Proteins from Faba Bean and Pea Flours and Collection of Wastewater Fractions}

Flours from faba beans (Vicia faba L.) and peas (Pisum sativum L.) provided by local farmers (Västra Götaland, Sweden) were utilized as the plant material for protein extraction. Both alkaline and acidic extraction processes were performed for each plant material based on the method reported by Swanson [12] with a few modifications. The alkaline extraction process was conducted by mixing $25 \mathrm{~g}$ of flour with distilled water in a ratio of 1:15 (w/v) and adjusting the $\mathrm{pH}$ to $9.5 \mathrm{using}$ $1 \mathrm{M} \mathrm{NaOH}$. The mixture was stirred for $1 \mathrm{~h}$ and then centrifuged at $3400 \mathrm{rpm}$ for $15 \mathrm{~min}$. The supernatant was retrieved, and its $\mathrm{pH}$ was adjusted to 4.5 using $0.5 \mathrm{M} \mathrm{HCl}$ to precipitate the proteins at this isoelectric point. The mixture was then centrifuged at $3400 \mathrm{rpm}$ for $15 \mathrm{~min}$, and the protein isolate was acquired while the supernatant was collected as the first wastewater fraction from the alkaline extraction. Subsequently, a washing step was conducted by mixing the protein isolate into distilled water $(1: 10 \mathrm{w} / \mathrm{v})$ for $5 \mathrm{~min}$ and then centrifuging the mixture at $3400 \mathrm{rpm}$ for $15 \mathrm{~min}$. The collected supernatant was designated as the second wastewater fraction from the alkaline extraction, while the precipitate was retained as the washed protein isolate.

The acidic extraction process was performed by progressively mixing $25 \mathrm{~g}$ of flour with acidified $(\mathrm{pH} 2.5)$ distilled water $(1: 15 \mathrm{w} / \mathrm{v})$, and a stable $\mathrm{pH}$ of 2.5 was maintained by continuous adjustment with $0.5 \mathrm{M} \mathrm{HCl}$. The mixture was stirred for $1 \mathrm{~h}$ and then centrifuged at $3400 \mathrm{rpm}$ for $15 \mathrm{~min}$. The supernatant was retrieved, and its $\mathrm{pH}$ was adjusted to the isoelectric point at $\mathrm{pH} 4.5$ using $1 \mathrm{M} \mathrm{NaOH}$, followed by centrifugation at $3400 \mathrm{rpm}$ for $15 \mathrm{~min}$. The protein isolate was acquired, and the supernatant was collected as the first wastewater fraction from the acidic extraction. Subsequently, a washing step was conducted by mixing the protein isolate with distilled water $(1: 10 \mathrm{w} / \mathrm{v})$ for 5 min and then centrifuging the mixture at $3400 \mathrm{rpm}$ for $15 \mathrm{~min}$. The collected was supernatant designated as the second wastewater fraction from the acidic extraction, while the precipitate was retained as the washed protein isolate.

\subsection{Characterization of the Faba Bean and Pea Wastewater Fractions}

Eight different wastewater fractions were obtained according to the type of matrix used (faba bean and pea flours), the type of extraction process applied (alkaline and acidic extractions), and the stage of the extraction process (first and second wastewater fractions). These wastewater fractions were characterized for their physicochemical parameters, which included chemical oxygen demand (COD), total solids (TS), total dissolved solids (TDS), electrical conductivity (EC), $\mathrm{pH}$, and turbidity.

Prior to the characterization process, the wastewater fractions were filtrated through two different filters of pore sizes $0.2 \mu \mathrm{m}$ (Acrodisc ${ }^{\circledR}$, Pall) and $0.1 \mu \mathrm{m}$ (Acrodisc ${ }^{\circledR}$, Pall) to evaluate the effect of membrane filtration. Subsequently, the physicochemical parameters of COD, TS, TDS, EC, $\mathrm{pH}$, and turbidity, were measured using the $0.2-\mu \mathrm{m}$ filtrates, while only TS, TDS, EC, and $\mathrm{pH}$ were measured for the 0.1- $\mu \mathrm{m}$ filtrates. COD was measured using a spectrophotometer (Spectroquant, NOVA 60, Merck) using the standard photometric method [13]. Total solids were determined using the APHA standard method 2540 B [13], and TDS were measured using a digital refractometer (HI 96801, Hanna Instruments). Electrical conductivity and pH were measured using a conductometer and $\mathrm{pH}$ meter, respectively (FiveGoTM equipped with LE407 and LE703 IP67 probes, Mettler-Toledo $\mathrm{GmbH}$ ). Turbidity was measured using a turbidimeter (Turbiquant $300 \mathrm{IR}$, Merck). 


\subsection{Analysis of High Value-Added Compounds}

Potential high value-added compounds in the wastewater fractions were identified and analyzed. The protein content in all the wastewater fractions was measured as described in a previous study for the analysis of the total protein content [14]. The carbohydrate content was analyzed after filtration through a $0.22-\mu \mathrm{m}$ filter (16532-K $0.22 \mu \mathrm{m}$, polyethersulfone, and high-flow syringe, Sartorius Minisart), and the individual separation and quantification were performed using an HPLCRefractive Index (HPLC-RI) Detector. The HPLC system (Merck Hitachi, Germany) was equipped with a column thermostat (Thermostat Merck L-5025 Column), an interface (Interface D-7000), an autosampler (AS-2000A Autosampler), a pump (L-6200 Intelligent Pump), and an RI detector (Elite LaChrom VWR Hitachi L-2490), and was controlled using software (D-7000 HSM). The analysis was conducted on a C8 column (Phenomenex Rezex RHM-Monosaccharide, $300 \mathrm{~mm} \times 7.80 \mathrm{~mm}, 8$ microns, $00 \mathrm{H}-0132-\mathrm{KO})$. The mobile phase was water in an isocratic gradient, used at a flow rate of $0.5 \mathrm{~mL} \mathrm{~min}{ }^{-1}$. The injection volume was $20 \mu \mathrm{L}$, and the total time of analysis was $25 \mathrm{~min}$.

The phenolic profile was analyzed through HPLC, while the total phenolic content was measured using the Folin-Ciocalteu reagent method [15] with a few modifications. Gallic acid was used as the standard for quantification, and the results were expressed as milligrams of gallic acid equivalents (mg GAeq). Prior to the identification and quantification of individual phenolic compounds in the samples, a concentration step through a solid-phase extraction cartridge (Chromafix C18 ec cartridge S; Macherey-Nagel) was conducted. The wastewater fractions were filtrated through the cartridge $(10 \mathrm{~mL})$ prior to being activated using methanol. The polyphenol fraction was retained in the cartridge and later eluted with methanol $(0.5 \mathrm{~mL})$. The methanolic fraction was then filtered using a 0.22- $\mu \mathrm{m}$ filter (Millipore Millex-GV, PVDF) and analyzed using HPLC-DAD-MSn/ESI.

The HPLC system was equipped with a diode array detector and a mass detector in series (HPLC 1100 Series, Agilent Technologies, Waldbronn, Germany), a binary pump (Model G1312A), an autosampler (Model G1313A), a degasser (Model G1322A), and a photodiode array detector (G1315B). The system was controlled using software ChemStation (Agilent, v.08.03). The mass detector was an ion-trap spectrometer (Model G2445A) equipped with an ESI interface that was controlled using software LCMSD (Agilent, v. 4.1). Mass spectrometry data were acquired in the negative ionization mode under the ionization conditions of $350^{\circ} \mathrm{C}$ temperature and $4 \mathrm{kV}$ voltage. Nitrogen was used as the nebulizer gas with a pressure of $65 \mathrm{psi}$ and a flow rate of $11 \mathrm{~L} \cdot \mathrm{min}^{-1}$. The full scan covered the mass range of $\mathrm{m} / \mathrm{z} 50$ to $\mathrm{m} / \mathrm{z} 1200$. Collision-induced fragmentation was performed using nitrogen as the collision gas and a voltage of $1 \mathrm{~V}$. Total ion chromatograms were recorded as full-scan mass spectra (MS), with the MS2 for the fragmentation of the three major significant fragment ions derived from the $[\mathrm{M}-\mathrm{H}]$ and MS3 breakdown of the significant fragment ions derived from the MS2. The analysis was conducted on a C18 HPLC column (Agilent Pursuit XRs $100 \AA, 250 \mathrm{~mm} \times 4 \mathrm{~mm}, 5 \mu \mathrm{m}$ particle size). The mobile phase consisted of two solvents - a mixture of water and formic acid in a ratio of 99:1 (v:v) (A) and acetonitrile (B). The gradient began with 3\% $B$ and reached $9 \%$ in a linear gradient at $5 \mathrm{~min}, 16 \%$ at $15 \mathrm{~min}, 50 \%$ at $50 \mathrm{~min}$, and $90 \%$ at $52 \mathrm{~min}$, and finally returning to the initial conditions at $57 \mathrm{~min}$. The total time of analysis was $62 \mathrm{~min}$, the flow rate was $0.8 \mathrm{~mL} \cdot \mathrm{min}^{-1}$, and the injection volume was $20 \mu \mathrm{L}$. The chromatograms were recorded at $280 \mathrm{~nm}, 320 \mathrm{~nm}, 340 \mathrm{~nm}, 360 \mathrm{~nm}$, and $520 \mathrm{~nm}$. The phenolic standards used for identification were weighed on a microanalytical balance $(0.001 \mathrm{mg})$ and then dissolved in methanol. Two groups 
of standards were prepared: 1) quercetin, caffeic acid, ferulic acid, and hydroxybenzoic acid, and 2) rutin and p-coumaric acid.

The antioxidant activity of the samples was analyzed using a previously reported protocol [16] with a few modifications, and the effective concentration (EC50) was calculated [17].

\subsection{Statistical Analysis}

All data were analyzed using PASW Statistics 25 for Windows (SPSS Inc., Chicago, IL, USA). Student t-test (independent two-sample t-test), with the significance threshold of $p<0.05$, was conducted for comparing the means in pairs. Student t-test was applied to study the variations in the parameters evaluated. The data were compared according to the stage of the extraction process (first and second wastewater fractions), the type of extraction (alkaline and acidic extraction fractions), and the type of matrix used (faba bean and pea flours). The filtered and unfiltered samples were grouped together for the statistical analysis (COD, TS, TDS, EC, and pH parameters) as the differences between them were not quantitatively relevant.

\section{Results and Discussion}

\subsection{Characterization of the Wastewater Fractions from Faba Bean and Pea Protein Extraction Processes}

In the case of the wastewater fractions acquired from faba bean, most of the evaluated parameters differed significantly $(\mathrm{p}<0.001)$ between the first and second fractions (Table 1$)$, with the COD, TS, TDS, and EC values approximately 66\%-89\%, 88\%-92\%, $89 \%-90 \%$, and $87 \%-90 \%$ higher, respectively, in the first fraction compared to the second one. In regard to the type of extraction, certain significant differences were observed, although these differences were not quantitatively relevant, except for the COD parameter measured in the second fraction $(p<0.001)$, which was approximately $59 \%$ higher in the acidic extraction than in the alkaline one.

Table 1 Physicochemical parameters of the wastewater fractions from the alkaline and acidic protein extractions from faba bean.

\begin{tabular}{llll}
\hline Parameters & Extraction type & \multicolumn{2}{l}{ Wastewater fractions } \\
\hline & & First & Second \\
COD $\left(\mathbf{m g} \cdot \mathrm{L}^{-1}\right)$ & Alkaline & $5940 \pm 165$ & $653 \pm 17 * * *$ \\
& Acidic & $4746 \pm 37$ & $1599 \pm 79 * * *$ \\
& & +++ & +++ \\
& & & \\
Total solids $\left(\mathbf{g} \cdot \mathrm{L}^{-1}\right)$ & Alkaline & $10.2 \pm 0.1$ & $0.8 \pm 0.1 * * *$ \\
& Acidic & $9.4 \pm 0.8$ & $1.1 \pm 0.2 * * *$ \\
& & + & ++ \\
Total dissolved solids $\left({ }^{\circ}\right.$ Brix) & Alkaline & $0.9 \pm 0.1$ & $0.1 \pm 0.1 * * *$ \\
& Acidic & $1.0 \pm 0.1$ & $0.1 \pm 0.0^{* * *}$ \\
\hline
\end{tabular}




\begin{tabular}{llll} 
Electrical conductivity $\left(\mathrm{mS} \cdot \mathrm{cm}^{-1}\right)$ & Alkaline & $4.02 \pm 0.06$ & $0.40 \pm 0.02 * * *$ \\
& Acidic & $4.49 \pm 0.40$ & $0.58 \pm 0.03 * * *$ \\
& & $\mathrm{~ns}$ & ++ \\
pH & Alkaline & $4.53 \pm 0.01$ & $4.64 \pm 0.04 * *$ \\
& Acidic & $4.46 \pm 0.01$ & $4.50 \pm 0.08 \mathrm{~ns}$ \\
& & +++ & + \\
\hline
\end{tabular}

Values are expressed as the mean \pm standard deviation of at least three replicates, corresponding to the data of all samples evaluated for each condition (unfiltered and filtered). The significant differences based on the extraction stage are presented in the same row, and those for the type of extraction are presented in the same column. Statistical analysis results according to Student t-test are denoted as $+(p<0.05),++(p<0.01),+++(p<0.001)$, and ns (not significant).

In the case of wastewater fractions from pea flour, most of the evaluated parameters differed significantly $(p<0.001)$ between the first and second fractions (Table 2$)$, with the COD, TS, TDS, and EC values approximately $86 \%-91 \%, 89 \%-91 \%, 88 \%-90 \%$, and $88 \%-90 \%$ higher, respectively, in the first fraction compared to the second one. In regard to the type of extraction, certain significant differences were observed, although these differences were not quantitatively relevant, except for the COD parameter measured in the second wastewater fraction $(p<0.001)$, which was higher [by approximately $36 \%$ ] in the acidic extraction fraction. When the impact of the matrix was compared (faba bean and pea), significant differences were observed, although quantitative differences were obtained only for the COD parameter measured in the first extraction stage $(p<0.001)$, which was approximately $25 \%-39 \%$ higher in the pea fraction than in the faba fraction, regardless of the type of extraction process used.

Table 2 Physicochemical parameters of the wastewater fractions from the alkaline and acidic protein extractions from pea.

\begin{tabular}{llll}
\hline Parameters & Extraction type & \multicolumn{2}{l}{ Wastewater fractions } \\
\hline & & First & Second \\
COD $\left(\mathbf{m g} \cdot \mathrm{L}^{-1}\right)$ & Alkaline & $7909 \pm 127$ & $700 \pm 37 * * *$ \\
& Acidic & $7794 \pm 332$ & $1095 \pm 45^{* * *}$ \\
& & $\mathrm{~ns}$ & +++ \\
& & & \\
Total solids $\left(\mathbf{g} \cdot \mathrm{L}^{-1}\right)$ & Alkaline & $9.2 \pm 0.3$ & $0.8 \pm 0.0^{* * *}$ \\
& Acidic & $9.8 \pm 0.4$ & $1.1 \pm 0.0^{* * *}$ \\
& & + & +++ \\
Total dissolved solids $\left({ }^{\circ}\right.$ Brix) & Alkaline & $0.8 \pm 0.1$ & $0.1 \pm 0.0 * * *$ \\
& Acidic & $1.0 \pm 0.1$ & $0.1 \pm 0.1 * * *$ \\
\hline
\end{tabular}




\begin{tabular}{llll} 
Electrical conductivity $\left(\mathbf{m s} \cdot \mathbf{c m}^{-1}\right)$ & Alkaline & $2.57 \pm 0.08$ & $0.30 \pm 0.00 * * *$ \\
& Acidic & $\begin{array}{l}4.13 \pm 0.20 \\
+++\end{array}$ & $\begin{array}{l}0.42 \pm 0.03 * * * \\
++\end{array}$ \\
& & & \\
pH & Alkaline & $4.58 \pm 0.02$ & $4.63 \pm 0.04 \mathrm{~ns}$ \\
& Acidic & $4.42 \pm 0.02$ & $4.17 \pm 0.04 * *$ \\
& & ++ & +++ \\
\hline
\end{tabular}

Values are expressed as the mean \pm standard deviation of at least three replicates, corresponding to the data of all samples evaluated for each condition (unfiltered and filtered). The significant differences for the extraction stage are presented in the same row, and those for the type of extraction are presented in the same column. The statistical analysis results according to Student t-test are denoted as $+(p<0.05),++(p<0.01),+++(p<0.001)$, and ns (not significant).

Recently, Chen et al. [2] indicated that the wastewaters from the food industry contained a high organic load, particularly the wastewater from the industries producing soybean products, which had high levels of COD (16000 mg. $\left.\mathrm{L}^{-1}\right)$, TS (18200 mg. L-1), and total suspended solids (TSS) (4000 $\left.\mathrm{mg} \cdot \mathrm{L}^{-1}\right)$. In the present study, the analysis of the first wastewater fractions revealed high COD and TS as the soluble inorganic, and organic matter present in the flour remained in the supernatant after the separation of the protein isolate. The second fraction exhibited a lower COD and TS, which was the result of the washing performed after the first extraction.

In addition, the results revealed that certain factors, such as the $\mathrm{pH}$ of the process, the type of extraction, and the matrix used, caused slight differences in the COD values. Therefore, all the fractions collected, regardless of the extraction stage, the type of extraction, and the matrix used, contained high loads of COD, which indicated a negative environmental impact in case of disposal and warranted the use of a wastewater recovery strategy.

Turbidity results also demonstrated significant differences between the wastewater fractions depending on the extraction stage and the type of extraction ( $p<0.001$ in most cases). Turbidity in the first extraction stage was approximately $90 \%-97 \%$ higher than that in the second stage, particularly in the alkaline extraction. In the acidic extraction, turbidity was approximately $60 \%-90 \%$ higher in the second extraction stage compared to the first one. As observed with the other evaluated parameters as well, turbidity results also indicated that the $\mathrm{pH}$ of the first extraction step of protein isolation was a critical influencing factor.

Wastewater treatment technologies, such as membrane filtration, ozonation, adsorption, and solvent extraction, might reduce the organic matter present in the wastewater fractions [2], thereby clearing the fractions and reducing the environmental impact in case of disposal. In the present study, membrane filtration was used as a first step in the treatment strategy to remove organic matter from the wastewater fractions, which resulted in a significant decrease $(p<0.001)$ in turbidity (Table 3 ). Reduction in turbidity has been previously associated with the decline of particulate COD [18]. Although this fraction obtained after filtration might also contain relevant products to be valorized, this analysis was not performed in the present study. The results demonstrated that filtration reduced approximately $85 \%-99 \%$ of turbidity, regardless of the type of 
extraction and the matrix used, which indicated that the reduction of particulate matter or total suspended solids was achieved after the filtration process and the dissolved solutes were recuperated in the effluent. Van Haute et al. [18] also observed a great decrease in turbidity along with a slight decrease in COD, indicating the negligible contribution of particulate matter to the total COD. According to the COD and TS values, it was inferred that the organic matter present in the wastewater fractions was constituted of dissolved solutes. Microfiltration (MF) (0.1-1.0 $\mu \mathrm{m}$ pore size) has been applied previously to remove suspended or particulate solids and organic colloids [19]. In the present study, MF or ultrafiltration (UF) $(0.01-0.1 \mu \mathrm{m}$ pore size) resulted in a clear reduction in particulate matter or total suspended solids in all the filtered wastewater fractions, while the dissolved constituents were not removed. In contrast, membrane technologies such as nanofiltration (NF) and reverse osmosis (RO), designed for the removal of dissolved chemical constituents, could be suitable for this purpose [20-22]. The rejection rate of NF is approximately $40 \%-60 \%$ of TDS in contrast to the value of $90 \%-98 \%$ achieved in RO [20-23]. These technologies, therefore, could be effective in series, i.e., using MF or UF as a pretreatment procedure. Aerobic and anaerobic digestions or flocculation, which have been previously applied in the treatment of wastewater from fruit and vegetable processing plants [2], could also be used for the wastewater fractions in the present study.

Table 3 Turbidity (NTU) of the wastewater fractions from the alkaline and acidic protein extractions from faba bean and pea flours and their corresponding filtrates.

\begin{tabular}{llllll}
\hline Matrix & Extraction type & \multicolumn{4}{l}{ Wastewater fractions and filtrates } \\
\hline & & First & First filtrate & Second & $\begin{array}{l}\text { Second } \\
\text { filtrate }\end{array}$ \\
Faba bean & Alkaline & $183.9 \pm 0.3$ & $1.7 \pm 0.1 * * *$ & $5.6 \pm 0.4$ & $0.2 \pm 0.0^{* *}$ \\
& Acidic & $9.2 \pm 0.2$ & $1.3 \pm 0.1 * * *$ & $73.5 \pm 4.9$ & $3.3 \pm 0.0^{* *}$ \\
& & +++ & & ++ & \\
Pea & & & & & \\
& Alkaline & $130.6 \pm 0.3$ & $4.4 \pm 0.3 * * *$ & $10.1 \pm 0.5$ & $0.1 \pm 0.0 * *$ \\
& Acidic & $12.7 \pm 0.3$ & $1.7 \pm 0.1 * * *$ & $39.7 \pm 0.0$ & $0.8 \pm 0.0 * * *$ \\
& & +++ & & ++ & \\
\hline
\end{tabular}

Values are expressed as the mean \pm standard deviation of 2 replicates. The significant differences for the same extraction stage and filtration are presented in the same row, and those for the type of extraction are presented in the same column. The statistical analysis results according to Student t-test are denoted as $+(p<0.05),++(p<0.01),+++(p<0.001)$, and ns (not significant).

\subsection{Potential Recovery of Proteins from the Wastewater Fractions from Faba Bean and Pea}

The efficiency of the protein extraction was measured indirectly by determining the total protein content in the wastewater fractions. The wet protein extraction process began with solubilizing the 
legume flour in an aqueous medium and adjusting the $\mathrm{pH}$ of the solution to either acidic or alkaline range far from the isoelectric point. Subsequently, the solubilized proteins were precipitated at the $\mathrm{pH}$ corresponding to their isoelectric point [24]. The impacts of the extraction stage, the type of extraction, and the matrix used were studied. Significant differences were observed when the fractions were compared based on the extraction stages (Figure 1). Protein content in the first wastewater fractions was approximately $65 \%-88 \%$ higher ( $p<0.01$ in most cases), regardless of the matrix used and the extraction type. These results demonstrated that a portion of protein did not precipitate at the isoelectric point while another was solubilized during the washing step after removing the protein isolate. In general, the protein content in the wastewater fractions indicated that after the extraction step, a portion of the soluble proteins remained in the supernatant (first wastewater fraction) even after the isoelectric precipitation. The protein loss might be related to the type of proteins, i.e., a few proteins might be soluble in the acidic or alkaline media, while having slightly different isoelectric points compared to the ones selected in the present study. Moreover, the presence of protein remaining in the supernatant even after precipitation could be attributed to the fact that certain proteins might require a longer time or a higher acid/alkali molarity for precipitation.
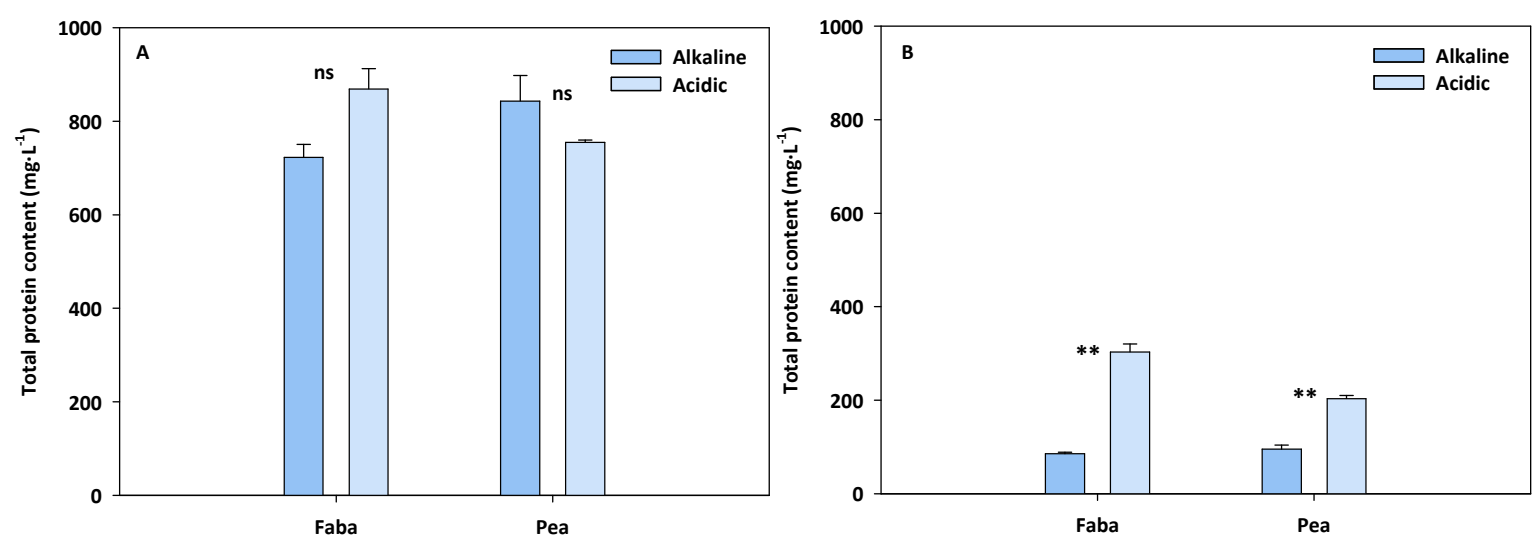

Figure 1 Total protein content in $(A)$ the first wastewater fractions from the alkaline and acidic protein extractions from faba bean and pea; $(B)$ the second wastewater fractions from the alkaline and acidic protein extractions from faba bean and pea. The significant differences for the type of extraction (alkaline/acidic) and in each extraction stage according to Student t-test are denoted as * $(p<0.05), * *(p<0.01), * * *(p<0.001)$, and ns (not significant).

When the type of extraction was compared in the statistical analysis, no differences were revealed in the first wastewater fractions, while significant differences were observed in the second wastewater fractions $(p<0.01)$. The protein content in the wastewater fractions from the acidic extraction from faba bean and pea was $72 \%$ and $53 \%$ higher, respectively, compared to the corresponding alkaline extraction fractions. The difference in the protein content between the acidic and alkaline treatment wastewater fractions could be attributed to the fact that the acidsolubilized proteins are closer to the isoelectric point compared to those solubilized under alkaline conditions. 
In regard to protein isolation efficiency, extraction using acidic media is reportedly a less favorable process due to lower cell wall degradation caused by the acid, which may lead to low protein diffusion to the acidic medium. Moreover, the applied acid $\mathrm{pH}$ is closer to the isoelectric point of the protein compared to the $\mathrm{pH}$ in the alkaline experiments, which results in lower protein solubility [25]. In general, alkaline extraction generates higher extraction yields compared to acidic extractions. Nevertheless, acidic extraction may be preferable in certain cases due to the different techno-functional properties of the extracts, besides preventing extreme $\mathrm{pH}$ conditions that may cause protein denaturation and high consumption of acids, alkalis, and water [26]. The protein content in the different isolates varied with the extraction $\mathrm{pH}$ and the legume type. Under both acidic and alkaline extraction conditions, the isolates from peas ( $\mathrm{pH} 2.5,99.5 \% \mathrm{DW} ; \mathrm{pH} 9.0,93 \% \mathrm{DW})$ exhibited a higher protein content compared to the faba bean isolates $(\mathrm{pH} \mathrm{2.5,88.9 \%} \mathrm{DW;} \mathrm{pH} 9.0$, $82.3 \% \mathrm{DW})$. In addition, both faba bean and pea isolates exhibited higher protein purity under acidic extraction.

Various technologies, such as foam separation or UF, have been applied to recover soybean protein from wastewaters [2]. A system based on two-stage foam separation technology reportedly achieved recoveries of approximately $80 \%$, while a combination of UF and RO has also been used for recovering soluble substances $[2,27,28]$. These technologies could be effective in the recovery of the remnant proteins present in the wastewater fractions.

\subsection{Potential Recovery of Carbohydrates from the Wastewater Fractions from Faba Bean and Peas}

The HPLC-RI analysis of the wastewater fractions revealed the presence of carbohydrates (Table 4). Among the four sugars investigated, namely, sucrose, fructose, glucose, and galactose, only sucrose was identified and quantified, and the rest were either not present or were at concentrations below the detection limit. The extraction stage, the type of extraction, and the impact of the matrix used were statistically analyzed. The analysis for sucrose revealed a higher content of approximately $82 \%-92 \%$ in the first wastewater fractions compared to the second ones $(p<0.001)$, regardless of the type of extraction and the matrix used. In addition, the sucrose content after the first acidic extraction from pea was higher (67\%) than that in the faba bean wastewater from acidic extraction $(p<0.001)$, while the reverse was observed under alkaline extraction. Kontos et al. [29] studied the methodologies for the recovery and purification of phenolic compounds from the carbohydrates blend in olive mill wastewater and observed that NF membranes were useful for separating both types of compounds, retaining approximately $95 \%$ of sucrose from tyrosol. The authors recommended applying a sequence of membrane technologies, such as vacuum distillation, freeze, drying, and melt crystallization, to recover value-added compounds from olive mill wastewater.

Table 4 Sucrose content $\left(\mathrm{mg} \cdot \mathrm{L}^{-1}\right)$ in the wastewater fractions from the alkaline and acidic protein extractions from faba bean and pea.

\begin{tabular}{llll}
\hline Matrix & Extraction type & Wastewater fractions & \\
\hline & & First & Second \\
Faba & Alkaline & $1598 \pm 29$ & $115 \pm 5^{* * *}$ \\
& Acidic & $726 \pm 21$ & $125 \pm 7^{* * *}$
\end{tabular}




\begin{tabular}{llll} 
& & +++ & ns \\
Pea & Alkaline & $1215 \pm 10$ & $138 \pm 13 * * *$ \\
& Acidic & $2168 \pm 147$ & $189 \pm 31 * * *$ \\
& +++ & ns \\
\hline
\end{tabular}

Values are expressed as the mean \pm standard deviation of 3 replicates. The significant differences for the extraction stage are presented in the same row, and those for the type of extraction are presented in the same column. The statistical analysis results according to Student $t$-test are denoted as $+(p<0.05),++(p<0.01),+++(p<0.001)$, and ns (not significant).

\subsection{Potential Recovery of Phenolic Compounds from the Wastewater Fractions from Faba Bean and Peas}

The analysis of the total phenolic content in the wastewater fractions was conducted, and the statistical analysis was performed concerning the extraction stage, the type of extraction, and the impact of the matrix used. The total phenolic content was approximately $81 \%-87 \%$ higher in the first wastewater fractions $(p<0.001)$ compared to the second one, regardless of the extraction type and matrix used (Figure 2). When the first wastewater fractions were compared, the phenolic content in the wastewater fraction from faba bean was approximately $34 \%-39 \%$ higher $(p<0.001)$ than that in the pea fraction, regardless of the type of extraction.
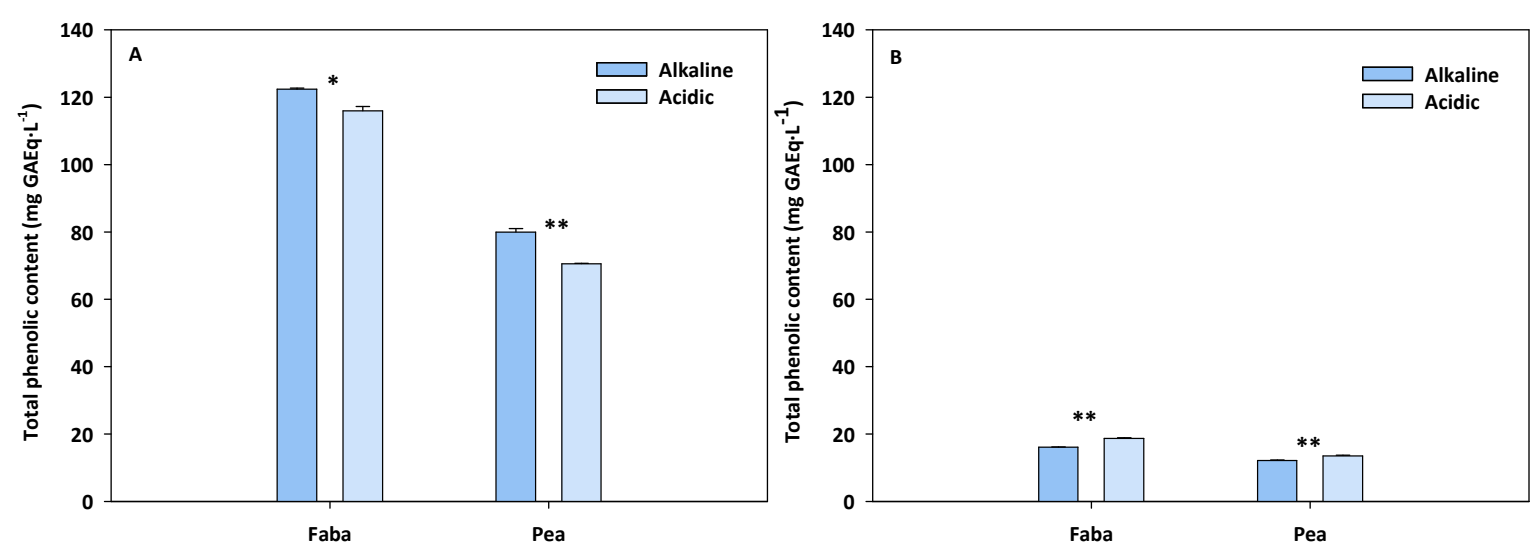

Figure 2 Total phenolic content in (A) the first wastewater fractions from the alkaline and acidic protein extractions from faba bean and pea; (B) the second wastewater fraction from the alkaline and acidic protein extractions from faba bean and pea. The significant differences for the type of extraction (alkaline/acidic) and in each extraction stage according to Student t-test are denoted as * $(p<0.05), * *(p<0.01),{ }^{* * *}(p<$ 0.001), and ns (not significant).

The identification and quantification of individual phenolic compounds were focused on the first wastewater fractions as these had the highest total phenolic content. The HPLC-DAD-MSn analysis of the wastewater fractions from faba bean and pea revealed differences in the individual phenolic compounds. The wastewater fractions from the alkaline and acidic extractions from faba bean had similar chromatograms with close signals and low-intensity peaks, rendering the identification 
difficult (Figure S1). Two main flavonoid glucosides identified were quercetin-rhamnoside-glucoside and kaempferol-rhamnoside-glucoside (Table 5). The content of kaempferol glucoside was double the quercetin content in both alkaline and acidic wastewater fractions. In pea wastewater fractions, the chromatograms for alkaline and acidic extractions were similar, with the peaks for more intense compared to those obtained for faba beans (Figure S2). Caffeic acid-glucoside, trans-feruloyl-malic acid, trans ferulic acid, trans-p-coumaroyl-malic acid, and p-hydroxy benzoyl-malic acid glucoside were identified and quantified using the corresponding standards (Table 6). In addition, the flavonoid kaempferol-triglucoside was identified and quantified as rutin. In pea, the content of phenolic compounds was slightly higher in the acidic fraction than in the alkaline fraction. 
Table 5 Characterization and quantification of phenolic compounds in the first wastewater fractions from the alkaline and acidic protein extractions from faba bean.

\begin{tabular}{|c|c|c|c|c|c|c|c|c|c|}
\hline & Group & Compound & $\begin{array}{l}\text { Rt } \\
(\min )\end{array}$ & $\begin{array}{l}\lambda \max \\
(\mathrm{nm})\end{array}$ & {$[\mathrm{M}-\mathrm{H}]^{-}$} & $\begin{array}{l}\mathrm{MS}^{2} \\
\text { fragments }\end{array}$ & $\begin{array}{l}\mathrm{MS}^{3} \\
\text { fragments }\end{array}$ & $\begin{array}{l}\text { Quantified } \\
\text { indirectly as }\end{array}$ & $\begin{array}{l}\text { Concentration } \\
\left(\mathrm{mg} \cdot \mathrm{L}^{-1}\right)\end{array}$ \\
\hline \multirow[t]{2}{*}{$\begin{array}{l}\text { Alkaline } \\
\text { extraction }\end{array}$} & Flavonoids & $\begin{array}{l}\text { Quercetin-rhamnoside- } \\
\text { glucoside }\end{array}$ & 21.8 & $\begin{array}{l}258 \\
356\end{array}$ & 609 & 447 & 301 & Quercetin & 0.15 \\
\hline & & $\begin{array}{l}\text { Kaempferol- } \\
\text { rhamnoside-glucoside }\end{array}$ & 23.9 & $\begin{array}{l}234 \\
266 \\
326\end{array}$ & 593 & 447,285 & & $\begin{array}{l}\text { Rutin } \\
\text { (Quercetin } \\
\text { 3-O- } \\
\text { rutinoside) }\end{array}$ & 0.30 \\
\hline \multirow[t]{2}{*}{$\begin{array}{l}\text { Acidic } \\
\text { extraction }\end{array}$} & Flavonoids & $\begin{array}{l}\text { Quercetin-rhamnoside- } \\
\text { glucoside }\end{array}$ & 21.9 & $\begin{array}{l}258 \\
356\end{array}$ & 609 & 447 & 301 & Quercetin & 0.14 \\
\hline & & $\begin{array}{l}\text { Kaempferol- } \\
\text { rhamnoside-glucoside }\end{array}$ & 23.9 & $\begin{array}{l}234 \\
266, \\
326\end{array}$ & 593 & 447,285 & & $\begin{array}{l}\text { Rutin } \\
\text { (Quercetin } \\
\text { 3-O- } \\
\text { rutinoside) }\end{array}$ & 0.33 \\
\hline
\end{tabular}

Table 6 Characterization and quantification of phenolic compounds in the first wastewater fractions from the alkaline and acidic protein extractions from pea.

\begin{tabular}{|c|c|c|c|c|c|c|c|c|c|}
\hline & Group & Compound & $\begin{array}{l}\text { Rt } \\
(\min )\end{array}$ & $\begin{array}{l}\lambda \max \\
(\mathrm{nm})\end{array}$ & $\begin{array}{l}{[\mathrm{M}-} \\
\mathrm{H}]^{-}\end{array}$ & $\begin{array}{l}\mathrm{MS}^{2} \\
\text { fragments }\end{array}$ & $\begin{array}{l}\mathrm{MS}^{3} \\
\text { fragments }\end{array}$ & $\begin{array}{l}\text { Quantified } \\
\text { as }\end{array}$ & $\begin{array}{l}\text { Concentration } \\
\left(\mathrm{mg} \cdot \mathrm{L}^{-1}\right)\end{array}$ \\
\hline \multirow[t]{2}{*}{$\begin{array}{l}\text { Alkaline } \\
\text { extraction }\end{array}$} & Flavonoids & $\begin{array}{l}\text { Kaempferol- } \\
\text { triglucoside }\end{array}$ & 22.9 & 264,346 & 771 & 609 & 285 & $\begin{array}{l}\text { Rutin (Quercetin 3-O- } \\
\text { rutinoside) }\end{array}$ & 0.92 \\
\hline & $\begin{array}{l}\text { Phenolic } \\
\text { acids }\end{array}$ & Caffeic acid-glucoside & 14.6 & 314 & 341 & 179 & 135 & Caffeic acid & 0.23 \\
\hline
\end{tabular}


Recent Progress in Materials 2021; 3(2), doi:10.21926/rpm.2102013

\begin{tabular}{|c|c|c|c|c|c|c|c|}
\hline $\begin{array}{l}\text { trans feruloyl-malic } \\
\text { acid }\end{array}$ & 19.2 & 240,320 & 308 & 193 & 134 & Ferulic acid & 0.91 \\
\hline trans ferulic acid & 24.8 & 238,324 & 193 & 149 & 134 & Ferulic acid & 0.62 \\
\hline $\begin{array}{l}\text { trans } \quad p \text {-coumaroyl- } \\
\text { malic acid }\end{array}$ & 16.9 & 236,308 & 278 & 163 & 119 & $p$-Coumaric acid & 0.64 \\
\hline $\begin{array}{l}p \text {-hydroxybenzoyl- } \\
\text { malic acid glucoside }\end{array}$ & 13.5 & 248 & 414 & 252 & 136 & Hydroxybenzoic acid & 0.57 \\
\hline $\begin{array}{l}\text { Kaempferol- } \\
\text { triglucoside }\end{array}$ & 22.9 & 264,346 & 771 & 609 & 285 & $\begin{array}{l}\text { Rutin (Quercetin 3-O- } \\
\text { rutinoside) }\end{array}$ & 1.25 \\
\hline Caffeic acid-glucoside & 14.6 & 314 & 341 & 179 & 135 & Caffeic acid & 0.35 \\
\hline $\begin{array}{l}\text { trans feruloyl-malic } \\
\text { acid }\end{array}$ & 19.3 & 240,320 & 308 & 193 & 134 & Ferulic acid & 1.09 \\
\hline trans ferulic acid & 24.9 & 238,324 & 193 & 149 & 134 & Ferulic acid & 0.45 \\
\hline $\begin{array}{l}\text { trans } \quad p \text {-coumaroyl- } \\
\text { malic acid }\end{array}$ & 17.0 & 236,308 & 278 & 163 & 119 & $p$-Coumaric acid & 0.75 \\
\hline $\begin{array}{l}p \text {-hydroxybenzoyl- } \\
\text { malic acid glucoside }\end{array}$ & 13.5 & 248 & 414 & 252 & 136 & Hydroxybenzoic acid & 0.79 \\
\hline
\end{tabular}


Polyphenols are well recognized for their antioxidant properties, as well as for their contribution to the prevention of various human illnesses (cardiovascular disease, cancer, osteoporosis, diabetes, and neurodegenerative diseases) [11]. Therefore, the recovery of these value-added compounds (polyphenols) from wastewater as by-products recovered from inexpensive input materials is important. In addition, this would be beneficial for wastewater recycling. Several methodologies have been applied to recover polyphenols from the wastewater fractions from fruit and vegetable processing industries. Membrane methodologies, such as NF with different molecular weights cutoffs, have been applied to recover flavonoids, including anthocyanins, from press liquors of orange peel, generating yields ranging from $70 \%$ to $89 \%$ [30]. Membrane technologies based on RO have reportedly been applied to recover isoflavones from whole soy milk [2, 31]. Moreover, foam fractionation followed by acidic hydrolysis and adsorption on chitosan microspheres has been used for separating isoflavone aglycone from soy whey wastewater [32]. Soybean isoflavones have also been obtained using wastewater protein extraction. However, most of these wastewater fractions are usually disposed of in sewage treatment plants $[2,33]$

\subsection{Antioxidant Activity of the Wastewater Fractions from Faba Bean and Peas}

As in the analysis of phenolic compounds, the antioxidant activity was also determined only in the first wastewater fractions as these fractions had higher polyphenol content. The extraction process and the matrix used were considered for statistical analysis, although significant differences were observed only for the type of matrix used. The effective concentration (EC50) in the pea wastewater fractions was approximately $84 \%-91 \%$, which was higher than that in the faba bean fractions, regardless of the type of extraction (Figure 3). A lower EC50 value represents a higher antioxidant activity. Therefore, the faba bean wastewater fractions exhibited higher antioxidant activity than the pea fractions.

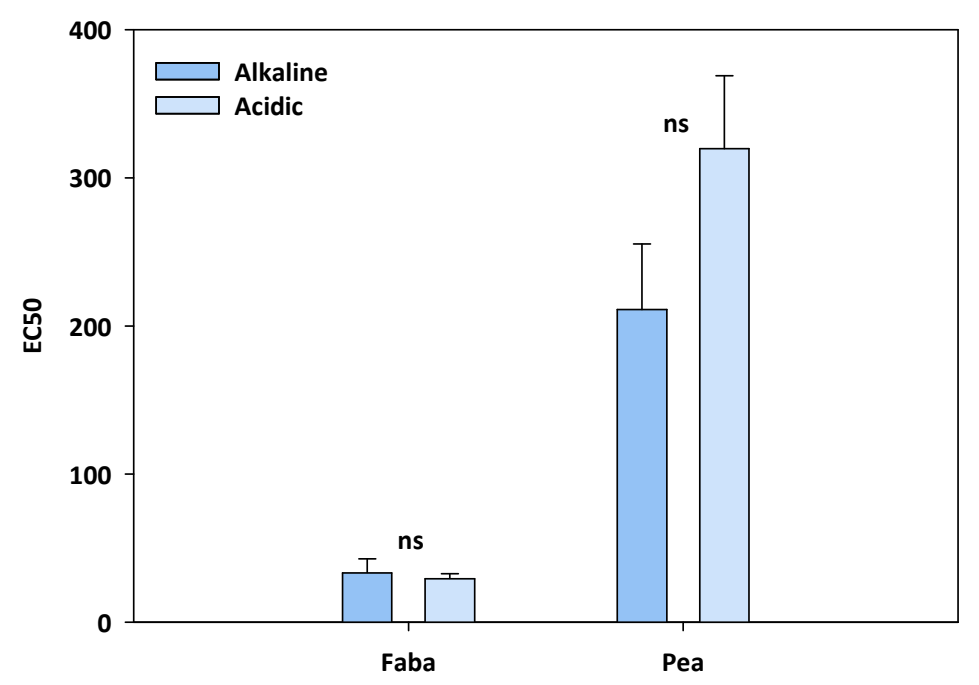

Figure 3 Antioxidant activity in the first wastewater fractions from the alkaline and acidic protein extractions from faba bean and pea. The significant differences for the type of extraction (alkaline/acidic) according to Student t-test are denoted as * $(p<0.05),{ }^{* *}(p$ $<0.01), * * *(p<0.001)$, and ns (not significant). 
While the total phenolic content was 34\%-39\% higher in the faba bean wastewater than in the pea fraction, the comparison of the antioxidant activities of the two matrices revealed higher differences, which could be associated with the presence of different polyphenol families in pea and faba bean wastewater fractions, as the total antioxidant activity is based on the synergistic effects of the polyphenols present, the metabolite type, and metabolite concentration [34].

\section{Conclusions}

Huge quantities of wastewater are generated in the industrial processes for the production of protein isolates, which are harmful to the environment. In the present study, all the wastewater fractions from faba bean and peas, particularly the first extraction stage fractions, were indicated to have a negative environmental impact owing to their high organic matter content, reflected as COD and total solids. It is suggested that membrane technologies focused on retaining the dissolved constituents should be implemented, in addition to microfiltration, to reduce the organic and inorganic loads originating from industrial food residues in the wastewater. Prior to implementing the cleaning and recycling strategies, the potential high value-added compounds, such as proteins, sucrose, and polyphenols, should be recovered from the first wastewater fractions, either by alkaline or acidic extraction. The first wastewater fraction from faba bean in the present study exhibited the highest total phenolic content and antioxidant activity, and was, therefore, considered most suitable for the potential valorization. Furthermore, approaches involving the recovery technologies specifically suitable for each group of value-added compounds, such as membrane technologies combined with physicochemical technologies, could also be implemented.

\section{Acknowledgments}

The authors are thankful for the financial support from the MINECO (Project AGL2016-75878-R) and Suit4food Erasmus+ of the European Union Programme (Grant Agreement Number 2017-1MT01-KA203-026962). Sofía Albolafio benefitted from a grant (BES-2017-079969). Authors are also grateful to Nathalie Hernández for their assistance.

\section{Additional Materials}

The following additional materials are uploaded on the page corresponding to the present paper.

1. Figure S1: HPLC-DAD chromatogram at $360 \mathrm{~nm}$ for the first wastewater fraction from the alkaline (A) and acidic (B) protein extractions from faba bean.

2. Figure S2: HPLC-DAD chromatogram at $320 \mathrm{~nm}$ for the first wastewater fraction from the alkaline $(A)$ and acidic $(B)$ protein extractions from pea.

\section{Author Contributions}

Sofía Albolafio: Formal analysis, Data curation, writing - original draft, Maria I Gil: Supervision, Writing -review \& editing, Ana Allende: Supervision, Epameinondas Xanthakis: Supervision, Writing -review. 


\section{Funding}

Authors are thankful for the financial support from the Ministerio de Ciencia e Innovación (Project AGL2016-75878-R), and European Project Erasmus + (2017-1-MT01-KA203-026962). Sofía Albolafio benefitted from a grant (BES-2017-079969).

\section{Competing Interests}

The authors have declared that no competing interests exist.

\section{References}

1. Houde M, Khodaei N, Benkerroum N, Karboune S. Barley protein concentrates: Extraction, structural and functional properties. Food Chem. 2018; 254: 367-376.

2. Chen H, Zhang H, Tian J, Shi J, Linhardt RJ, Ye TD, et al. Recovery of high value-added nutrients from fruit and vegetable industrial wastewater. Compr Rev Food Sci Food Saf. 2019; 18: 13881402.

3. Casani S, Rouhany M, Knøchel S. A discussion paper on challenges and limitations to water reuse and hygiene in the food industry. Water Res. 2005; 39: 1134-1146.

4. Manzocco L, Ignat A, Anese M, Bot F, Calligaris S, Valoppi F, et al. Efficient management of the water resource in the fresh-cut industry: Current status and perspectives. Trends Food Sci Technol. 2015; 46: 286-294.

5. Barać MB, Pešić MB, Stanojević SP, Kostić AŽ, Čabrilo SB. Techno-functional properties of pea (Pisum sativum) protein isolates: A review. Acta Period. Technol. 2015; 46: 1-18.

6. Bhatty RS. Chemical composition of some faba bean cultivars. Can J Plant Sci. 1974; 54: 413-421.

7. Warsame AO, O'Sullivan DM, Tosi P. Seed storage proteins of faba bean (Vicia faba L): Current status and prospects for genetic improvement. J Agric Food Chem. 2018; 66: 12617-12626.

8. Lam AC, Can Karaca A, Tyler RT, Nickerson MT. Pea protein isolates: Structure, extraction, and functionality. Food Rev Int. 2018; 34: 126-147.

9. Turco I, Ferretti G, Bacchetti T. Review of the health benefits of Faba bean (Vicia faba L.) polyphenols. J Food Nutr Res. 2016; 55: 283-293.

10. Millar KA, Gallagher E, Burke R, McCarthy S, Barry-Ryan C. Proximate composition and antinutritional factors of fava-bean (Vicia faba), green-pea and yellow-pea (Pisum sativum) flour. J Food Compost Anal. 2019; 82: 103233.

11. Cassano A, Conidi C, Ruby-Figueroa R, Castro-Muñoz R. Nanofiltration and tight ultrafiltration membranes for the recovery of polyphenols from agro-food by-products. Int J Mol Sci. 2018; 19: 351.

12. Swanson BG. Pea and lentil protein extraction and functionality. J Am Oil Chem Soc. 1990; 67: 276-280.

13. APHA. Standard methods for the examination of water and waste water. 21st ed. Washington, DC: American Public Health Association; 2014.

14. Bradford MM. A rapid and sensitive method for the quantitation of microgram quantities of protein utilizing the principle of protein-dye binding. Anal Biochem. 1976; 72: 248-254.

15. Singleton VL, Rossi JA. Colorimetry of total phenolics with phosphomolybdic-phosphotungstic acid reagents. Am J Enol Vitic. 1965; 16: 144-158. 
16. Brand-Williams W, Cuvelier ME, Berset CL. Use of a free radical method to evaluate antioxidant activity. LWT Food Sci Technol. 1995; 28: 25-30.

17. Kagliwal LD, Patil SC, Pol AS, Singhal RS, Patravale VB. Separation of bioactives from seabuckthorn seeds by supercritical carbon dioxide extraction methodology through solubility parameter approach. Sep Purif Technol. 2011; 80: 533-540.

18. Van Haute S, Uyttendaele M, Sampers I. Coagulation of turbidity and organic matter from leafyvegetable wash-water using chitosan to improve water disinfectant stability. LWT Food Sci Technol. 2015; 64: 337-343.

19. del Pino MP, Durham B. Wastewater reuse through dual-membrane processes: Opportunities for sustainable water resources. Desalination. 1999; 124: 271-277.

20. Warsinger DM, Chakraborty S, Tow EW, Plumlee MH, Bellona C, Loutatidou S, et al. A review of polymeric membranes and processes for potable water reuse. Prog Polym Sci. 2018; 81: 209237.

21. Wilf $M$. The guidebook to membrane technology for wastewaterreclamation. 1st ed. Hopkinton: Balaban Publishers; 2010. pp.788.

22. Bartels C, Franks R, Andes K. Operational performance and optimization of RO wastewater treatment plants. Singapore: Singapore International WaterWeek; 2010. pp.12.

23. Tchobanoglous G, Cotruvo J, Crook J, McDonald E, Olivieri A, Salveson A, et al. Framework for direct potable reuse. Alexandria, VA: WateReuseResearch Foundation; 2015. pp.211.

24. Hadnađev MS, Hadnađev-Dapčević T, Pojić MM, Šarić BM, Mišan AČ, Jovanov PT, et al. Progress in vegetable proteins isolation techniques: A review. Food Feed Res. 2017; 44: 11-21.

25. Sari YW, Bruins ME, Sanders JP. Enzyme assisted protein extraction from rapeseed, soybean, and microalgae meals. Ind Crops Prod. 2013; 43: 78-83.

26. Pojić M, Mišan A, Tiwari B. Eco-innovative technologies for extraction of proteins for human consumption from renewable protein sources of plant origin. Trends Food Sci Technol. 2018; 75: 93-104.

27. Jiang C, Wu Z, Li R, Liu Q. Technology of protein separation from whey wastewater by two-stage foam separation. Biochem Eng J. 2011; 55: 43-48.

28. Hang $X$, Chen X, Luo J, Cao W, Wan Y. Removal and recovery of perfluorooctanoate from wastewater by nanofiltration. Sep Purif Technol. 2015; 145: 120-129.

29. Kontos SS, Katrivesis FK, Constantinou TC, Zoga CA, loannou IS, Koutsoukos PG, et al. Implementation of membrane filtration and melt crystallization for the effective treatment and valorization of olive mill wastewaters. Sep Purif Technol. 2018; 193: 103-111.

30. Conidi C, Cassano A, Drioli E. Recovery of phenolic compounds from orange press liquor by nanofiltration. Food Bioprod Process. 2012; 90: 867-874.

31. Xu L, Lamb K, Layton L, Kumar A. A membrane-based process for recovering isoflavones from a waste stream of soy processing. Food Res Int. 2004; 37: 867-874.

32. Liu W, Wu ZL, Wang YJ, Li R, Yin NN, Jiang JX. Separation of isoflavone aglycones using chitosan microspheres from soy whey wastewater after foam fractionation and acidic hydrolysis. J Ind Eng Chem. 2015; 25: 138-144.

33. Wang HJ, Murphy PA. Isoflavone content in commercial soybean foods. J Agric Food Chem. 1994; 42: 1666-1673.

34. Xanthakis E, Theodosiou E, Magkouta S, Stamatis H, Loutrari H, Roussos C, et al. Enzymatic transformation of flavonoids and terpenoids: Structural and functional diversity of the novel 
Recent Progress in Materials 2021; 3(2), doi:10.21926/rpm.2102013

derivatives. Pure Appl Chem. 2010; 82: 1-16.

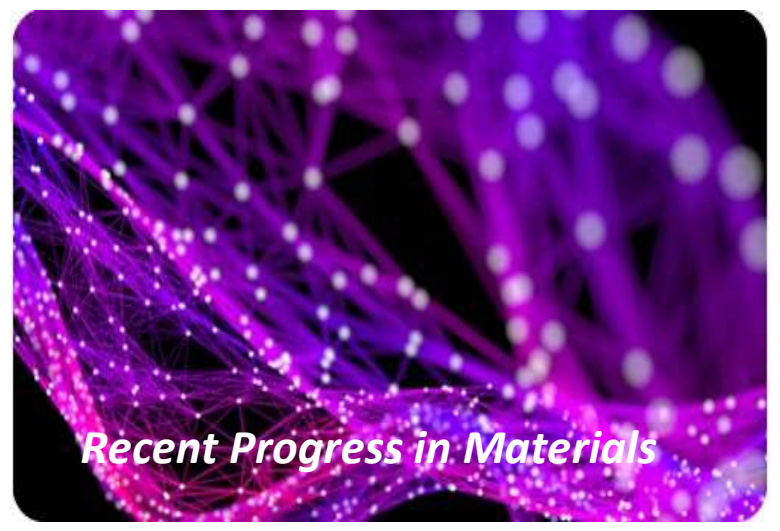

Enjoy Recent Progress in Materials by:

1. Submitting a manuscript

2. Joining in volunteer reviewer bank

3. Joining Editorial Board

4. Guest editing a special issue

For more details, please visit:

http://www.lidsen.com/journals/rpm 